\title{
A comparison of calculated and determined apparent ileal digestibility of amino acids in cereal- soyabean diets for young pigs
}

\author{
W. Urynek ${ }^{1}$ and L. Buraczewska ${ }^{2}$
}

\author{
'Degussa-Hüls $A G$ \\ 00-193 Warszawa, Poland \\ ${ }^{2}$ The Kielanowski Institute of Animal Physiology and Nutrition, \\ Polish Academy of Sciences \\ 05-110 Jablonna, Poland
}

\begin{abstract}
The digestibility experiment was carried out on twelve cannulated pigs between 14 and $27 \mathrm{~kg}$ body weight. The animals were fitted with a PVTC cannula and fed with two starter diets, A and B, differing in metabolizable energy content (13.5 and $14.5 \mathrm{MJ} \mathrm{ME} / \mathrm{kg}$, respectively), with no supplemented amino acids (AA), in order to measure digestibility coefficients of protein-bound AA. The diets were formulated to contain $0.6 \mathrm{~g}$ ileal digestible lysinc/MJ $\mathrm{ME}$ and were calculated on the basis of AA analysis of ingredients and their tabular values of apparent ileal AA digestibilities. For both diets, differences between the calculated and determined digestibilities of the limiting essential AA were found. The determined digestibilitics tended to be lower than the calculated ones. Of the cssential AA, the differences were greatest for threonine ( 6.8 and $9.5 \%$ of calculated values for diet $\mathrm{A}$ and $B$, respectively) and lysine ( 4.3 and $8.3 \%$ for diet $A$ and $B$, respectively); the differences for methionine and tryptophan ranged from 4.0 to $6.2 \%$. In conclusion, the present study shows that the digestible AA supply in a diet can be predicted from total AA content determined in the individual ingredients and from average literature values recommended for their AA digestibility, however, it is necessary to accept an $8-10 \%$ error for calculated values.
\end{abstract}

KEY WORDS: ileal digestibility, amino acids, young pigs

\section{INTRODUCTION}

The nutritive value of protein in feedstuffs is not only determined by its total amino acid (AA) content, but also by AA digestibility, with particular reference to the limiting AA. For formulation of pig diets, apparent ileal AA digestibility coef- 
ficients of feeds, presented as average values of many literature data, are recommended (e.g., Rademacher et al., 1999). However, considerable variations in apparent digestibility values of AA in many feeds were reported. For example, lysine digestibility in wheat samples ranged from 59 to $80 \%$ (Sauer and Ozimek, 1986; Fan et al., 2001). Large variability was also found for other feeds like barley (Sauer and Ozimek, 1986) rapeseed meal (Buraczewska et al., 1987) and soyabean meal (Fan et al., 1996). The aim of our studies was to formulate diets for piglets containing a determined level of apparent ileal digestible AA, c.g., $0.6 \mathrm{~g}$ digestible lysine/MJ ME. For this purpose, the chosen cereal and high-protein ingredients were analyzed for their total AA content and their levels of ileal digestible AA were calculated using the digestibility coefficients recommended by Degussa-Hüls (Rademacher et al., 1999). The objective of this study was to compare the calculated and determined content of ileal digestible AA in order to test the adequacy of tabular coefficients for diet formulation. Ileal digestibility of dietary AA was determined on cannulated pigs.

\section{MATERIAL AND METHODS}

\section{Animals and experimental design}

The experiment was carried out on twelve castrated male crossbred piglets (synthetic line 990), surgically fitted with post-valvular T-caecum cannula (PVTC) according to van Leeuwen et al. (1991). After cannulation the piglets were fed two experimental diets (6 pigs per diet) during two experimental periods at about 15 and $25 \mathrm{~kg}$ body weight (BW), according to the change-over design. Each period consisted of at least 7 days adjustment to the diets, followed by 3 days ( $12 \mathrm{~h}$ each) collection of ileal digesta.

\section{Formulation of diets and feeding program}

Two starter diets A and B, containing 13.5 (A) and 14.5 (B) MJ ME/kg and $0.6 \mathrm{~g}$ ileal digestible lysine/MJ ME were formulated on the basis of chemical analysis of dietary ingredients, including AA (Table 1), their tabular ileal digestibility coefficients (Table 2) and "ideal protein", recommended by Degussa-Hüls for pigs (Rademacher et al., 1999). Apart from digestible lysine, all other essential AA were balanced in the diets composed of seven protein-containing ingredients, as described in Urynek and Buraczewska (2001). Chromic oxide $\left(\mathrm{Cr}_{2} \mathrm{O}_{3}\right)$ was used as a marker. The pigs were fed two equal portions daily at 08.00 and $20.00 \mathrm{~h}$ in accordance with BW (5\%). The unpelleted feed was mixed with water (1:1) just before feeding. Water was supplied ad libitum. 
TABLE 1

Chemical composition $\left(\mathrm{g} \mathrm{kg}^{-1}\right)$, ME value $\left(\mathrm{MJ} \mathrm{kg}^{-1}\right)$ and $\mathrm{AA}, \%$ of dietary ingredients (as-fed)

\begin{tabular}{lccccccc}
\hline & Wheat & Barley & Maize & $\begin{array}{c}\text { Soyabean } \\
\text { meal }\end{array}$ & $\begin{array}{c}\text { Soyabean } \\
\text { protein } \\
\text { conc. }\end{array}$ & $\begin{array}{c}\text { Ful fat } \\
\text { soya } \\
\text { (Soyax) }\end{array}$ & $\begin{array}{c}\text { Fish } \\
\text { meal }\end{array}$ \\
\hline Dry matter & 883 & 882 & 888 & 908 & 910 & 913 & 932 \\
Crude protein & 128 & 131 & 95 & 490 & 552 & 357 & 633 \\
Ether extract & 17.7 & 16.8 & 42.8 & 14.7 & 7.2 & 197 & 68 \\
Ash & 18.7 & 21.4 & 14.4 & 61.3 & 67.1 & 48.9 & 226.0 \\
Starch & 476 & 420 & 541 & 24.2 & 21.1 & 18.8 & - \\
Sugar & 25.2 & 31.8 & 15.8 & 75.0 & 32.5 & 57.3 & - \\
Crude fibre & 32.1 & 47.2 & 31.9 & 45.9 & 33.8 & 70.9 & - \\
NDF & 118.3 & 186.0 & 114.9 & 107.7 & 77.9 & 113.0 & - \\
ADF & 44.3 & 57.3 & 43.7 & 69.5 & 45.8 & 97.1 & - \\
Calculated ME & 13.84 & 12.68 & 14.15 & 13.59 & 14.28 & 16.02 & 14.50 \\
& & & & & & & \\
Amino acids & & & & & & & \\
lysine & 0.36 & 0.41 & 0.31 & 3.05 & 3.00 & 2.15 & 4.04 \\
methionine & 0.20 & 0.21 & 0.17 & 0.64 & 0.73 & 0.46 & 1.70 \\
cystine & 0.30 & 0.28 & 0.20 & 0.77 & 0.84 & 0.51 & 0.52 \\
threonine & 0.37 & 0.42 & 0.34 & 1.91 & 2.15 & 1.37 & 2.37 \\
tryptophan & 0.14 & 0.16 & 0.08 & 0.64 & 0.75 & 0.48 & 0.52 \\
\hline
\end{tabular}

TABLE 2

Apparent ileal AA digestibility cocfficients of dictary ingredients (Rademacher et al., 1999), \%

\begin{tabular}{lccccccc}
\hline Amino acids & Barley & Maize & Wheat & $\begin{array}{c}\text { Soyabcan } \\
\text { meal }\end{array}$ & $\begin{array}{c}\text { Soyabean } \\
\text { protein } \\
\text { concentrate }\end{array}$ & $\begin{array}{c}\text { Ful fat } \\
\text { soya }^{2}\end{array}$ & $\begin{array}{c}\text { Fish } \\
\text { meal }\end{array}$ \\
\hline Lysine & 67 & 62 & 75 & 88 & 93 & 86 & 88 \\
Methionine (Met) & 77 & 82 & 85 & 89 & 91 & 85 & 88 \\
Met+Cystine & 74 & 76 & 84 & 84 & 91 & 80 & 84 \\
Threonine & 65 & 63 & 72 & 83 & 90 & 78 & 86 \\
Tryptophan & 67 & 65 & 80 & 85 & 89 & 83 & 84 \\
\hline
\end{tabular}

1 according to Jondréville et al., 1995; ${ }^{2}$ according to CVB, 1990 
Sampling, analysis and calculations

Ileal digesta was collected using bags attached to the cannulas during the three days for $12 \mathrm{~h}$ per day, between 8.00 and $20.00 \mathrm{~h}$. The bags were changed approximately every hour and their contents were immediately frozen in plastic containers at $-20^{\circ} \mathrm{C}$. After each collection, samples were thawed, pooled per animal within each experimental period, freeze-dried and ground $(\phi 0.5 \mathrm{~mm})$ before chemical analysis. $\mathrm{Cr}_{2} \mathrm{O}_{3}$ in samples of feeds and freeze-dried digesta was analyzed by the method of Fenton and Fenton (1979). Dry matter, nitrogen, ether extract, crude fibre, total starch and ash werc analyzed using standard methods (AOAC, 1990). The content of NDF and ADF was determined using a Fibertec System (according to the instruction).

AA were analyzed with a high-pressure amino acid analyzer, Biochrom 20, according to Llames and Fontaine (1994). Methionine and cystine were determined after oxidation with performic acid. Tryptophan was determined by reversedphase-high-performance liquid chromatography (HPLC) following alkaline hydrolysis with barium hydroxide. The apparent ileal AA digestibilities were determined according to the relevant equations (Rademacher et al., 1999). ME of dietary ingredicnts was calculated from the determined chemical composition of feeds (Table 1) using a corrected equation (Hoffmann and Schicmann, 1980).

\section{RESULTS AND DISCUSSION}

Determined AA digestibility values were similar for diets A and B (Table 3). There were differences between the calculated and determined digestibilities of the limiting essential AA in both diets (Table 4). The determined digestibilities tended to be lower than the calculated ones and these differences were more pronounced in diet $\mathrm{B}$ than $\mathrm{A}$. Of the essential $\mathrm{AA}$, the differences were largest for threonine (6.8 and $9.5 \%$ for diets $A$ and $B$, respectively) and lysine ( 4.3 and $8.3 \%$ for diets $\mathrm{A}$ and $\mathrm{B}$, respectively). For both diets, smaller differences ranging from 4.0 to $6.2 \%$ were observed for methionine and tryptophan.

TABLE 3

Apparent ileal digestibility cocfficients of basic aminoacids: means \pm S.D., $\%$

\begin{tabular}{lcc}
\hline & Dict A & Diet B \\
\hline Methionine & $82.2 \pm 2.7$ & $81.6 \pm 2.9$ \\
Cystine & $77.5 \pm 2.9$ & $76.3 \pm 3.5$ \\
Lysine & $79.4 \pm 3.0$ & $79.1 \pm 3.0$ \\
Threonine & $72.7 \pm 3.6$ & $72.5 \pm 3.9$ \\
Tryptophan & $77.0 \pm 3.0$ & $77.0 \pm 3.5$ \\
\hline
\end{tabular}


TABLE 4

Calculated and determined content of digested (apparent, ilcal) amino acids in diets A and B, \% as-fed

\begin{tabular}{|c|c|c|c|c|c|c|}
\hline & \multicolumn{3}{|c|}{ Diet $A$} & \multicolumn{3}{|c|}{ Diet $B$} \\
\hline & calculated & determined & difference' & calculated & determined & difference \\
\hline Ileal digestible lysine & 0.810 & 0.778 & -4.32 & 0.870 & 0.798 & -8.28 \\
\hline Ileal digestible methionine & 0.272 & 0.260 & -4.41 & 0.292 & 0.273 & -6.16 \\
\hline Ileal digestible cystine & 0.300 & 0.291 & -3.00 & 0.291 & 0.295 & +1.37 \\
\hline Ileal digestible threonine & 0.561 & 0.523 & -6.77 & 0.588 & 0.532 & -9.52 \\
\hline Ileal digestible tryptophan & 0.198 & 0.189 & -4.55 & 0.201 & 0.193 & -3.98 \\
\hline
\end{tabular}

1 expressed in percent of calculated values

It is commonly known that many factors, including methodological approaches, fineness of grinding, dietary AA level and AA distribution among protein fractions (e.g., in cereals), NDF content (affected by genotype and growing conditions), temperature used in feed processing, level of antinutritional factors, and content of undigested endogenous protein at the ilcum, are likely responsible for the variation of AA digestibility values reported in the literature. Additionally, there may be associative effects that cause the digestible supply of AA in a mixture of feeds to differ from the sum based on the digestibilities determined in the individual ingredients. Imbeah et al. (1988) reported that there were no differences between the calculated and observed digestibilities of the essential AA in a feed mixture of barley and soyabean meal, however, there were significant differences in lysine $(10.5 \%)$ and phenylalanine $(5.4 \%)$ content in a mixture of barley and rapeseed meal.

In conclusion, the present study shows that the digestible AA supply in a diet can be predicted from the total $A \Lambda$ content determined in the individual ingredients and from average literature values recommended for the particular AA digestibility, however, it is necessary to accept an $8-10 \%$ error of the calculated values.

\section{REFERENCES}

AOAC, 1990. Official Methods of Analysis. Association of ()fficial Analytical Chemists. $15^{\text {th }}$ Edition. Washington, DC

Buraczewska L., Schulz E, Schröder H., 1987. Ileal digestibility of amino acids in pigs fed barleys differing in protein content. Arch. Anim. Nutr. (Berlin) 10,861-867

CVB, 1990. Voorlopige tabel schijnbaar vertreerbare aminozauren in veevoedergrondstoffen voor varkens. CVB-reeks nr 2, Juli 1990, Central Veevoederbureau, Lelystad (The Netherlands) 
Fan M.Z., Sauer W.C., Gabert V.M., 1996. Variability of apparent ileal amino acid digestibility in canola meal for growing-finishing pigs. Can. J. Anim. Sci. 76, 563-569

Fan M.Z., Sauer W.C., Li S., 2001. Variability of apparent ileal amino acid digestibility in highprotein wheat samples for growing-finishing pigs. J. Anim. Feed Sci. 10, 103-118

Fenton T.W., Fenton M., 1979. An improved procedure for the determination of chromic oxide in feeds and faeces. Can. J. Anim. Sci. 59, 631-634

Hoffmann L., Schiemann R., 1980. Von dem Kalorie, zum Joule: Neue Grossenbeziehungen bei Messungen des Energieumsatzes und bei der Berechung van Kennzahlen der Energetischen Futterbewertung. Arch. Tieremähr. 30, 733-742

Imbeah M., Sauer W.C., Mosenthin R., 1988. The prediction of the digestible amino acid supply in barlcy-soybean meal or canola meal diets and pancreatic enzyme secretion in pigs. J. Anim. Sci. $66,1409-1417$

Jondréville C., Van den Broecke J., Gatel F, Van Cauwenberghe S., 1995. Ileal digestibility of amino acids in feedstuffs for pigs. Eurolysinc, ITFC (France)

Llames C.R., Fontaine J., 1994. Determination of amino acids in feeds: collaborative study. J. AOAC Int. $77,1362-1402$

Rademacher M., Sauer W.C., Jansman A.J.M., 1999. Standardized Ileal Digestibility of Amino Acids in Pigs. New System. Degussa-Hüls, Frankfurt/Main

Sauer W.C., Ozimek L., 1986. Digestibility of amino acids in swine: results and their practical application. A review. Livest. Prod. Sci. 15, 367-388

Urynek W., Buraczewska L.,2001. Effect of growth period at about 15 and $25 \mathrm{~kg}$ body weight on amino acid digestibility in young pigs. J. Anim. Feed Sci. 10, Suppl. 2, 147-152

Van Leeuwen P.J., van Kleef D.J., van Kempen G.J.M., Huisman J., Verstegen M.W.A., 1991. The post valve $\mathrm{T}$-caecum cannulation technique in pigs applicated to determine the digestibility of amino acids in maize, groundnut and sunflower meal. J. Anim. Physiol. Anim. Nutr. 65, 183-193

\section{STRESZCZENIE}

Porównanie obliczonej ì oznaczonej pozornej strawności jelitowej aminokwasów u młodych świń żywionych mieszankami zbożowo-sojowymi

Doświadczenie strawnościowe przeprowadzono na 12 prosiçtach o masie ciała od 14 o $27 \mathrm{~kg}$. Prosiętom założono proste kaniule (PVTC), a po wyzdrowieniu karmiono 2 mieszankami starter A i B, różniącymi sic̨ zawartością energii metabolicznej, odpowiednio 13,5 i 14,5 MJ EM/kg. Zastosowano dwa okresy żywienia w układzie przemicnnym. Micszanki o zawartości $0,6 \mathrm{~g}$ strawnej lizyny/ MJ EM i odpowiedniej proporcji innych niezbędnych AA, przygotowano na podstawie analizy AA w składnikach mieszanek $i$ ich tabelarycznych współczynników pozornej strawności. Dla obydwóch mieszanek stwierdzono różnice między strawnością obliczoną a oznaczoną niezbędnych AA limitujących; współczynniki strawności oznaczone były niższe niż obliczone. Wśród AA niezbędnych różnice procentowe były największe dla treoniny $(6,8$ i $9,5 \%$, odpowiednio dla mieszanek $\mathrm{A}$ i B) oraz lizyny $(4,3$ i $8,3 \%$, odpowiednio dla micszanck A i B). Dla obydwóch mieszanek w przypadku metioniny i tryptofanu różnice wyniosły od 4,0 do $6,2 \%$.

Podsumowując, wyniki doświadczenia wskazują, że poziom AA strawnych w mieszance może być przewidziany na podstawie oznaczonej zawartości AA w poszczególnych surowcach oraz ich średnich współczynników strawności podawanych w literaturze, należy jednak przyjąć możliwość błędu, od 8 do $10 \%$, wyliczonych wartości. 